\title{
TINDAK KEKERASAN YANG DILAKUKAN ANAK-ANAK SEBAGAI UPAYA UNTUK MEMECAHKAN MASALAH YANG DIAKIBATKAN TEKANAN LINGKUNGAN
}

\author{
Witrin Gamayanti
}

Fakultas Psikologi UIN Sunan Gunung Djati Bandung

Violent behaviors conducted by children were unimaginable by our mind that we have set our mind that children are group of people who still innocent, and the hope for our future. Violence-in our mind -is perhaps the trait that labeled to some thugs, robbers, and many criminals whose world are full of violence they lived in. What is happening with our society and our children? Violence conducted by children can be seen as social behavior disturbance since there are violations to the moral values and humanity, family and society normative rules. Violent behavior - verbal and non verbal - including bad attitudes and behaviors that disturb many our environment are violation to what we call as society norms and laws. Children who conducted violent behavior were not a result of instant process but a cumulative result of many aspects they have seen, heard and felt in daily life. Aggression and anti social behavior are a learned behavior which means that children learned it from imitation process from something and someone who they meet, see, heard and copied.

Keywords: Juveniles delinquency, problem solving.

\section{Latar Belakang}

Beberapa tahun kebelakang kita dikejutkan oleh peristiwa seorang anak berusia 12 tahun yang masih duduk dibangku SD kelas 5 membunuh teman mainnya sendiri yang berusia 5 tahun dan masih sekolah ditaman kanak-kanak. Pembunuhan yang dilakukannya cukup sadis dan rasanya tindakan itu suatu hal yang mustahil dilakukan oleh anak seusianya. Teman main yang dianggap telah menyinggung perasaannya yaitu telah meledek dan mengata-ngatai sehingga memunculkan marah dan dendam yang berakibat pada hilangnya nyawa seseorang. Cara yang dilakukan dengan menjerat leher memakai tali plastik, setelah tidak berdaya dan lemas kemudian mengiris nadi pergelangan tangan kanan dan kiri korban menggunakan silet. Setelah itu ia pulang dan berperilaku seperti tidak pernah terjadi apa-apa. Bahkan ketika semua orang termasuk kepolisian mencari, ia ikut mencari dan sempat mengelabui polisi dengan cerita yang dikarangnya. Kekerasan yang berakibat hilangnya nyawa seseorang juga terjadi di beberapa daerah lainnya. Ketika ditanya alasan melakukan hal itu, dikarenakan merasa kesal dan merasa tersinggung di ejek terus-terusan. Adalagi kasus yang tidak kalah menariknya yaitu banyaknya anak yang "nge-fans" meniru gaya dari salah satu program acara televisi yang cukup akrab dengan mereka yaitu smackdown yang mengakibatkan beberapa anak menjadi korban, mereka dengan lugunya mempraktekan semua yang mereka lihat tanpa berpikir akibatnya. 
Lain halnya dengan $\mathrm{X}$ yang berusia 15 tahun ia berani membunuh bapaknya sebagai pembelaan terhadap ibu kandungnya karena tidak tahan melihat ibu yang selalu disiksa. Ia membacok kepala bapaknya dengan sebilah kapak hingga tewas. Sebetulnya masih banyak peristiwa yang tidak terpotret oleh mata masyarakat tetapi itu hadir dan ada di depan mata kita. Tetapi pada intinya adalah hilangnya kendali emosi pada saat seorang anak dihadapkan pada situasi yang menekan atau menyinggung perasaannya yang mengakibatkan ia berperilaku di luar kewajaran.

Fenomena di atas membuat kita berpikir kenapa seorang anak sanggup melakukan hal seperti itu? kalau kita mencoba menerawang sedikit kemasa lalu kita dulu, masalah dengan teman, persaingan, rebutan mainan, saling mengejek, bermusuhan karena masalah sepele, memukul teman atau saudara rasanya bukan suatu hal yang asing. Bahkan hampir semua anak pernah merasakan itu baik dengan saudara kandungnya sendiri atau dengan teman sekolah dan teman mainnya. Reaksi dari mereka ketika berhadapan dengan kemarahan dan kekesalan bermacam-macam ada yang menangis, berteriak, " memboikot " teman dan tidak mau main lagi dengannya, mengadu pada orang tuanya. Tetapi beberapa hari kemudian atau beberapa jam bahkan menit kemudian mereka sudah tertawa dan bercanda lagi seperti nya peristiwa yang membuatnya marah itu tidak pernah terjadi. Selama itu tidak menjadi kebiasaannya, menangis, marah, bentrok dengan teman itu merupakan sebuah kewajaran, hal itu merupakan dinamika dalam berso- sialisasi justru disana anak belajar bagaimana mengatur emosi dan menyesuaikan diri dengan ling-kungan sosial, melakukan sesuatu yang bisa diterima oleh lingkungannya. Tetapi manakala gesekan dengan masalah menimbulkan ledakan emosi yang tidak terkontrol itu akan menjadi sesuatu yang luar biasa. Emosi menguasai akal sehatnya, memunculkan tindakan irasional, tindak kekerasan yang membuat hati semua orang tua merasa miris.

Sementara bayangan kita tentang anak adalah mahluk yang polos, berpikir sederhana, tempat digantungkannya do'a dan harapan semua pihak supaya dimasa depan lebih baik. Rasanya tindakan mereka hanya layak dan bisa kita mengerti kalau dilakukan oleh seorang penjahat kelas kakap yang telah begitu akrab dengan tindakan kejahatan. Apa sebetulnya yang sedang terjadi pada diri anak-anak kita sekarang?

\section{Tinjauan Teoritis}

Tindakan kekerasan yang dilakukan anak bisa dikategorikan kedalam gangguan tingkah laku sosial. Banyak istilah yang sering digunakan untuk mengambarkan gangguan ini diantaranya conduct disorder, juvenile delinquent, externalizing behavior, uncontrolled bahavior, antisocial behavior definisi ini memperlihatkan berbagai pendekatan yang digunakan untuk menggambarkan apa dan bagaimana gangguan ini terjadi serta bagaimana konsekuensi bagi diri dan lingkungan juga antisipasi kedepannya.

Conduct disorder adalah tingkah laku yang tidak tepat/ tidak sesuai dengan usianya, perilaku anak yang melanggar harapan ke- 
Tindak Kekerasan yang Dilakukan Anak-Anak Sebagai Upaya untuk Memecahkan Masalah yang Diakibatkan Tekanan Lingkungan (Witrin Gamayanti)

luarga, norma sosial dan personal serta melanggar hak orang lain. Anak yang mengalami gangguan tingkah laku memperlihatkan tingkah laku (behavior) yang mengganggu dan melanggar aturan seperti merengek, sumpah serapah/mengutuk, temper tantrum, kekerasan, mencuri dan menyerang.

Mash membagi beberapa definisi gangguan tingkah laku ini ke dalam beberapa pendekatan yaitu definisi hukum, psikologi, pskiatri dan berdasarkan public health

a. Definisi hukum, yaitu tingkah laku delinquent atau tindakan kriminal yang mengakibatkan seseorang ditangkap atau adanya kontak dengan pelanggaran norma aturan sopan santun

b. Menurut pandangan psikiatri, yaitu gangguan tingkah laku dilihat sebagai gangguan mental yang jelas berdasarkan simptom yang terdapat pada DSM IV. Disebut sebagai disruptive behavior disorder termasuk didalamnya oppositional defiant disorder.

c. Definisi kesehatan masyarakat, adalah gabungan dari berbagai disiplin ilmu atau pendekatan hukum, psikologi, psikiatri, dengan konsep kesehatan masyarakat bagaimana prevensi dan intervensinya;

d. Dari sudut pandang psikologi, menurut Mash, gangguan tingkah laku terletak sepanjang dimensi dari tingkah laku yang diluar kewajaran (externalizing behavior) dimana di dalamnya terdapat gabungan antara impulsiv, over active, aggresif, dan delinquent act.
Dimensi externailizing behavior terdiri dari dua hal yang saling berhubungan tetapi masing-masing subdimensi berdiri sendiri yaitu delinquent dan aggresif. Delinquent adalah pelanggaran tingkah laku seperti kabur dari rumah, bermain api, mencuri, bolos sekolah, menggunakan alkohol dan obat-obatan terlarang dan melakukan tindak kekerasan. Agresif termasuk di dalamnya adalah berkelahi, merusak, tidak patuh, pamer, menyimpang, mengancam serta menjadi pengganggu disekolah. Conduct disorder (CD) menggambarkan anak yang memperlihatkan pola tingkah laku yang agresif dan antisosial yang relatif menetap dan mengakibatkan penderitaan kepada orang lain atau mengganggu hak orang lain dengan pisik, dan verbal agresi, mencuri, dan melakukan tindakan kekerasan.

Berdasarkan definisi yang disajikan diatas bisa disimpulkan bahwa gangguan tingkah laku adalah pelanggaran terhadap norma aturan masyarakat dan keluarga disertai tindak kekerasan dalam bentuk verbal dan non verbal maupun tindakan yang merugikan diri dan lingkungannya dimana didalamnya ada pelanggaran dan perampasan terhadap hak orang lain.

Ada empat kategori masalah tingkah laku, yaitu: 1) Overt-covert, dimensi berada pada range tindakan yang mudah terlihat seperti berkelahi sampai kepada tindakan yang tersembunyi seperti berbohong dan mencuri. Anak yang memperlihatkan overt antisocial behavior cenderung negatif, gampang tersinggung, mudah marah ketika mereka dihadapkan pada situasi yang penuh permusuhan dan mempunyai pengalaman dengan 
keluarga yang penuh konflik. Sebaliknya anak yang memperlihatkan covert antisocial behavior yaitu kurang bersosial, lebih cemas, curiga terhadap orang lain, dan biasanya datang dari rumah yang kurang memberikan dukungan.

Anak-anak seperti ini biasanya memperlihatkan konflik dengan figur otoritas, memperlihatkan adanya gangguan / penyimpangan dalam hubungan antar keluarga dan hal ini mengakibatkan permasalahan yang berkepanjangan; 2) Destructive - Nondestructive, Sementara itu destructive-nondestructive berada pada range dimensi, melakukan tindakan kekejaman pada binatang atau melakukan penyerangan fisik hingga nondestructive yaitu membantah atau gampang tersinggung.

Berdasarkan usia, seorang anak dikatakan mengalami gangguan tingkah laku berawal pada usia sebelum 10 tahun minimal terdapat satu simptom. Gangguan tingkah laku ini kalau tidak ditangani dengan tuntas akan menjadi prekursor dari gangguan selanjutnya ketika anak menginjak usia dewasa yaitu APD (antisocial personality disorder).

Hal yang penting pada anak-anak yang mengalami CD yaitu kurang peduli dengan orang lain dan menempatkan mereka pada posisi yang termasuk kedalam kelompok yang mempunyai resiko tinggi untuk menjadi agresi dan anti sosial. Mereka terllihat kurang mempunyai perasaan, dan unemotional interpersonal style. Karakteristiknya adalah kurang merasa bersalah, tidak memperlihatkan empati, tidak memperlihatkan emosi, narsis dan impulsiv.
Remaja yang mengalami CD (Conduct disorder) mempunyai karakteristik kurang bisa menampakan perasaan malu, gagal dalam meredam emosi dan gagal bertingkah laku sesuai dengan norma sosial.

2. Simptom Gangguan Tingkah Laku Menurut DSM IV

a. Agresi kepada manusia dan binatang

1) Sering kali menggertak, mengancam, dan mengintimidasi orang lain;

2) Memulai perkelahian fisik;

3) Menggunakan senjata yang dapat menyebabkan kerusakan fisik yang mengerikan

4) Kekejaman yang dilakukan pada manusia

5) Kekejaman yang dilakukan pada binatang

6) Mencuri dengan berhadapan langsung dengan korban misalnya merampas dompet, memeras, perampokan bersenjata

7) Memaksa seseorang untuk melakukan aktifitas seksual.

b. Merusak milik orang lain

1) Dengan sengaja menyalakan api dengan maksud untuk melakukan kerusakan

2) Dengan sengaja merusak properti orang lain.

c. Kebohongan dan pencurian

1) Merusak rumah, bangunan atau mobil seseorang.

2) Berbohong untuk mendapatkan keuntungan atau menghindari kewajiban

3) Mencuri tanpa berhadapan langsung dengan korban misalnya pencurian di toko, pemalsuan. 
Tindak Kekerasan yang Dilakukan Anak-Anak Sebagai Upaya untuk Memecahkan Masalah yang Diakibatkan Tekanan Lingkungan (Witrin Gamayanti)

d. Pelanggaran Serius Terhadap Aturan

1) Berada diluar rumah pada malam hari sebelum usia menginjak 13 tahun

2) Kabur dari rumah

3) Bolos sekolah sebelum berusia 13 tahun.

3. Penyebab Terjadinya Gangguan

Pada dasarnya agresi merupakan tingkah laku yang dipelajari dan merupakan inti dari CD. Anak-anak belajar menjadi agresi melalui punishment yang diberikan oleh lingkungan sebagai konsekuensi dari tingkah lakunya.

Penyebab yang saling mempengaruhi sehingga terjadinya gangguan ini adalah:

a. Anak; Resiko genetik, komplikasi karena pralahir dan pada saat lahir, temperamen yang sulit, ADHD, merasa tidak aman, awal kejadian agresi, menghindari dan menarik diri dari sosial, kurangnya kognisi sosial, rendahnya kecerdasan dan kemampun verbal.

b. Keluarga; Nilai keluarga yang antisosial, orang tua yang kriminal atau anti sosial, paternal mengalami gangguan kepribadian antisosial, maternal depresi, kekerasan yang dilakukan orang tua, pernikahan yang tidak harmonis, single parent, keluarga besar, status sosial ekonomi keluarga rendah, pendidikan ibu yang rendah, kurangnya kepedulian dari keluarga terhadap kepemilikan senjata.

c. Pola asuh yang tidak efektif; Kurangnya pengawasan dan monitoring, disiplin yang tidak konsisiten, disiplin yang terlalu keras dan salah perlakuan, hubungan orang tua anak yang tidak harmonis, komunikasi yang rendah, penolakan / pengabaian orang tua, kurang hangat.

d. Peer; Penolakan peer, berkumpul dengan sibling yang meyimpang, bergabung dengan peer yang menyimpang.

e. Sekolah; Performance akademik yang rendah, aspirasi pendidikan rendah, motivasi sekolah rendah, kurang mengenal sekolah dan fungsinya;

f. Tetangga dan masyarakat; Tetangga yang kurang mendukung dan miskin, lingkungan sekitar rumah yang kurang tertata, menjadi anggota gang, kemudahan mendapatkan senjata;

g. Sosiokultural, Media yang banyak menayangkan kekerasan, kulltural yang mendorong untuk melakukan tindakan agresi, pengenanalan agresi pada anak.

\section{Pola Asuh Orang Tua Yang Ekstrem}

Kaitannya Dengan Conduct Disorder adalah:

a. Tidak konsisten dalam menanamkan aturan dan disiplin. Ketidakkonsistenan orang tua dalam menetapkan aturan membuat anak menjadi bingung kapan aturan tersebut bisa dilanggar kapan harus ditaati. Kapan hal tersebut bisa dilakukan kapan menjadi terlarang. Ketidakkonsistenan ini juga menyebabkan anak bebas mengatur dan berkesimpulan ada saatnya saya boleh melakukan sesuatu yang sebelumnya dilarang tanpa analisa lebih jauh.

b. Permissive. Orang tua yang cenderung untuk membolehkan anak melakukan apapun tanpa kontrol dan arahan yang benar. Tidak ada aturan yang bisa dijadikan pe- 
gangan atau koridor-koridor yang tidak bisa di langgar. Anak bebas melakukan apapun tanpa sanksi/punishment ataupun reward sebagai buah dari apa yang telah dia lakukan. Masalahnya akan muncul manakala anak tumbuh dengan temperament yang sulit dan impulsif tanpa arahan dan rambu yang jelas akan mengembangkan tindakan agresifnya dan mempersepsi bahwa hal tersebut sesuatu yang wajarwajar saja.

c. Restrictive dan orientasi kekuasaan. Sebaliknya dari pemaparan yang tadi. Anak tumbuh dalam iklim keluarga yang terbiasa dengan kekerasan. Terlalu kaku dalam menerapkan aturan tanpa penjelasan yang bisa dipahami anak, kenapa itu boleh dan kenapa tidak boleh. Anak dipaksa untuk menurut tanpa feed back lebih jauh mengenai tingkah laku dan kosekuensi dari tingkah lakunya. Tidak seimbang antara reward \& punishment, manakala anak melakukan suatu kebaikan tidak ada penghargaan yang layak yang membuat anak mengerti bahwa apa yang dilakukannya adalah sebuah kebaikan. Sebaliknya pada saat anak salah punishment akan siap menyambutnya tanpa penjelasan lebih jauh kenapa anak dihukum.

d. Dimensi afek cenderung didominir oleh permusuhan. Hukuman demi hukuman yang dialami anak membuat mereka belajar untuk menghukum dan melakukan kekerasan seperti yang selama ini ia lihat dan dengar. Makian, pukulan menjadi pelajaran sehari-hari. Keringnya kasih sa- yang yang dirasakan sehingga mempersepsi setiap hukuman adalah bentuk dari permusuhan yang di rasakan oleh orang tua terhadap mereka. Hal ini menurunkan nilai-nilai moral anak tentang kebaikan, kasih sayang, menghargai.

5. Treatment dan pencegahan

Menurut Mash ada tiga cara efektif yang bisa dilakukan dalam menangani permasalahan CD ini.

a. Parent Management Training (PMT); Mengajarkan pada orang tua untuk merubah tingkah laku anak-anak mereka dirumah dengan menggunakan metode contingency management technique. Fokus pada memperbaiki interaksi antara orang tua anak dan meningkatkan keterampilan orang tua dalam hal komunikasi orang tua anak, monitoring, pengawasan.

b. Problem Solving Skills Training (PSST); Mengetahui kekurangan kognisi dan penyimpangan dalam situasi sosial dan menyediakan instruksi, latihan serta feed back untuk mengajarkan cara baru dalam mengatasi situasi sosial. Anak belajar untuk menghargai situasi, merubah pe-mikiran anak terhadap anak lain, lebih sensitif terhadap perasaan anak yang lain, dengan alternatif yang lebih banyak dan solusi lebih tepat;

c. Multisystematic Treatment (MST); Pendekatan yang intensif yang menggambarkan teknik-teknik seperti PMT, PSST dan terapi perkawinan. Dengan menggunakan terapi yang memanfaatkan intervensi khu- 
Tindak Kekerasan yang Dilakukan Anak-Anak Sebagai Upaya untuk Memecahkan Masalah yang Diakibatkan Tekanan Lingkungan (Witrin Gamayanti)

sus, program khusus oleh lembaga yang berhak melakukan.

\section{Pembahasan}

Anak-anak yang melakukan tindak kekerasan bukan hasil dari sebuah proses yang instant tetapi merupakan kumulatif dari berbagai sebab yang mereka alami selama ini. Seperti yang dikemukakan sebelumnya bahwa tingkah laku agresi dan anti sosial adalah sebuah tingkah laku yang dipelajari. Artinya anak-anak bisa melakukan tersebut salah satunya adalah hasil dari imitasi dan identifikasi dari sesuatu atau sesorang yang sering ia lihat dan dengar.

Seperti yang kita ketahui anak adalah peniru terbaik sedunia, ia gampang sekali mengadopsi apapun yang menurut mereka menarik atau yang sering mereka lihat dalam keseharian. Tanpa pertimbangan atau filter yang ketat mengenai hal tersebut. Belum berfungsinya filter anak dalam menyaring respon sosial sesuai dengan norma karena kemampuan kognisi anak belum berkembang dengan optimal, masih sangat longgar dan belum bisa memilah/menyelekasi mana yang baik dan buruk secara tepat. Justru disini peran orang tua dan lingkungan tempat dimana ia tinggal yang sangat besar untuk mengarahkan anak menjadi lebih baik. Karena kemampuan menirunya yang luar biasa itulah sebetulnya kita bisa meramalkan dari kondisi keluarga seperti apa, hidup dilingkungan seperti apa, anak-anak yang sanggup melakukan tindakan kekerasan apalagi sampai berani menghilangkan nyawa seseorang dengan sengaja.
Perekonomian negara yang carut-marut membuat banyak sekali rakyat kita yang berada dibawah kemiskinan. Umumnya orang yang berada di bawah kemiskinan mempunyai banyak tekanan/stres untuk memenuhi kebutuhan hidupnya. Sangat masuk akal kalau orang tua pada akhirnya berkonsentrasi penuh untuk berusaha memenuhi kebutuhan anak dengan bekerja apapun yang sanggup ia kerjakan. Energi yang orang tua punya lebih terserap kepada bagaimana memenuhi kebutuhan perut keluarga mereka. Sehingga tingkat stres mereka cukup tinggi dalam menghadapi kehidupan. Konsekuensinya perhatian mereka terhadap anak menjadi semakin berkurang. Anak lebih banyak menghabiskan waktu tanpa supervisi dan kontrol orang tua. Sementara bukan rahasia lagi lingkungan masyarakat kita sudah semakin longgar dalam memegang norma sosial maupun nilai-nilai agama. Belum lagi mudahnya mereka mengakses berbagai informasi yang negatif maupun positif tanpa mengeluarkan biaya yang banyak. Contohnya televisi, banyak sekali menayangkan kekerasan, pembunuhan, perampokan. Film-film yang menayangkan aksi kekerasan bisa dengan mudah dan murah dilihat oleh mereka.

Di sisi lain, masih banyak orang tua yang belum mempunyai pengetahuan yang memadai mengenai pola asuh yang efektif bagi anak mereka. Tingkah laku yang negatif dari anak disikapi dengan kekerasan, cacian, pukulan yang pada akhirnya menambah proses belajar anak dalam melihat dan meniru bagaimana suatu masalah dihadapi. 
Tidak heran kalau anak ikut merasa stres dengan kondisi yang tidak nyaman ini. Sementara informasi yang ia terima selama ini adalah jauh dari kebenaran. Pengaruh teman main dan lingkungan sangat besar dalam mewarnai sikap seorang anak. Begitu juga dengan lingkungan sekolah. Kita harus mengakui dengan jujur banyak sekolah di negara kita yang dijalankan baru sebatas menyentuh aspek kognisinya saja. Pengelolaan mental dan emosi masih luput dari kurikulum yang ada. Otomatis yang terasah selama ini adalah kemampuan akalnya. Sementara mental spiritualnya tidak berkembang secepat kemampaun kognisi. Sehingga saringan anak dalam menyeleksi informasi yang masuk kurang ditelaah dengan berbagai pertimbangan.

Hal di atas menyebabkan anak kurang memiliki keterampilan dalam mengungkapkan perasaan, mengekspresikan emosi dengan tepat dan benar. Tingkat stres yang tinggi, kurangnya belajar keterampilan menghadapi permasalahan dengan benar, sementara itu berbagai tingkah laku dan informasi yang tidak tepat yang sebetulnya belum saatnya mereka lihat dan dengar telah akrab dengan keseharian mereka. Maka solusi yang ia lakukan untuk mengatasi ketidaknyamanannya, kekesalan adalah meniru apa yang ia alami dan lihat selama ini.

\section{Simpulan}

Semakin banyaknya anak yang mengalami gangguan tingkah laku sebetulnya semakin menunjukan betapa bobroknya kehidupan kita saat ini. Anak yang mengalami gangguan atau menjadi juvenil delinquent adalah hasil dari proses belajar mereka untuk menjadi seperti itu. Pelajaran gratis yang ia bisa dapatkan dengan bebas dimana saja. Dilingkungan masayarakat, rumah, sekolah, teman-temannya, media informasi seperti televisi, buku dan masih banyak lagi.

Sudah saatnya berbagai pihak, orang tua, lingkungan masyarakat, sekolah terutama pemerintah berbenah diri lebih peka dan sensistif terhadap perubahan dan kemerosostan akhlak anak-anak bangsa. Karena selama lingkungan tidak berubah atau hanya salah satu pihak saja yang melakukan perubahan tidak akan menghasilkan sesuatu yang signifikan bagi perkembangan anak-anak kita. Karena mereka, anak-anak kita cukup pintar untuk mengakses apapun yang dia mau dari berbagai sumber yang ada. Baik di lingkungan rumah atau lingkungan sosial yang lebih luas. Walaupun terdengar cukup klise tapi kebenarannya tidak bisa dibantahkan yaitu kekuatan agama yang harus masuk dan lebih besar mewarnai pertumbuhan anak-anak kita saat ini. Disamping itu keberadaan orang tua sebagai figur yang senantiasa diimitasi dan menjadi figur identifikasi anak, semakin menyadari pentingnya contoh perilaku yang baik untuk membentuk perilaku anak-anaknya. Yang harus diingat apabila anak ditampar maka ia belajar menampar orang, ketika anak dimaki ia belajar memaki orang, ketika anak disakiti ia belajar menyakiti orang dan ketika anak dicintai ia belajar mencintai orang. 


\section{Daftar Pustaka}

Al-Maghribi, Al-Maghribi bin as-Said. (2004). Begini Seharusnya Mendidik Anak: Panduan mendidik anak sejak masa kandungan hingga dewasa. Terjemahan Zaenal Abidin. Jakarta: Darul Haq.

Hurlock, E. B. (1981). Developmental Psychology. TMH Edition. New Delhi: Tata McGraw-Hill Publishing Company Ltd. . (1991). Psikologi Perkembangan : Suatu Pendekatan Sepanjang Rentang Hidup. Terjemahan Dra. Istiwidayanti dkk. Jakarta : Erlangga.

Lerner, R.M. \& Hultsch, D.F. (1983). Human Devlopment: A Life-Span Perspektive. New York : McGraw-Hill, Inc.

Laura, E. Berk. (1993). Infants, Children, \& Adolescents. Illionois State University: Allyn \& Bacon

Marat, S. \& Siregar, J.R. (1991). Diktat Pengantar Psikologi Perkembangan. Bandung: Fakultas Psikologi Universitas Padjadjaran

Monks,F.J.et.al. (1994). Psikiologi Perkembangan: Pengantar dalam Berbagai Bagiannya. Yogyakarta: Gadjah Mada University Press

Nashori, F. (2003). Potensi-potensi Manusia : Seri Psikologi Islami. Yogyakarta: Pustaka Pelajar

Papalia, D.E., \& Olds, S.W. (1995). Human Development. $6^{\text {th }}$ Edition. New York : McGraw-Hill, Inc. . et.al. (2002). A Child's World: Infancy Through Adolescence. $9^{\text {th }}$ Ed. New York: McGraw-Hill, Inc.

Qardhawi Yusuf. (1990). Metode Pendidikan Ikhwanul Muslimin.

Santrock, J.W. (1986). Life-Span Development. $2^{\text {nd }}$ Edition. Dubuque, Lowa : Wm. C. Brown Publishers.

Suwaid, M.I.A.H. (2004). Cara Nabi Mendidik Anak. Terjemahan Hamin Thohari 
Psympathic, 2009, Vol. I, No.1: 63-72 